propterea invidisse dicitur, quod, Hippolyto ad vitam revocato, iura Plutonis imminuisset. Nunc autem omnibus penitus persuasum est, nihil quod hominum saluti prosit, summo Patri posse displicere. Non immerito igitur illos in honore habemus, quorum auxilio mortis imperium inter terminos artiores contractum vidimus.

Mr. Ernest Henry Starling, M.D., F.R.S., Professor of Physiology, University College, Lonđon.

Agmen nostrum claudit hodie Universitatis Londiniensis in Collegio quodam illustri professor insignis. Physiologis notum est sanguinis nostri partem quandam e venis quibusdam subtilissimis per corporis telas propinquas textu tenuissimas exsudare, et coıpori alimenta quaedam nova ministrare. Viri huius praesertim experimentis sudoris illius ratio universa explicata est, qui etiam vitam corporis iam mortui in corde et pulmonibus conservatam, et partium superstitum motus, investigare potuit. Talium virorum ingenio, vocabulo quodam a lingua Graeca derivato, quod hormone dicitur, res quaedam chemica patefacta est, quae, ex alia corporis parte intima, parti alii stimulos addit, hinc illuc velut nuntia quaedam transmissa. Etiam physiologiae in studio quicquid novi aliunde ad nos advectum est, etiam nobis novos stimulos addit. Ergo etiam hunc virum, rerum exterarum nuntium ad nos advectum, decoramus, qui tot collegas suos non modo industriae et laboris sed etiam gloriae et honoris stimulis concitavit.

\section{THE CARNEGIE FOUNDATION FOR THE ADVANCEMENT OF TEACHING.}

THE annual report of the president of the Carnegie Foundation for the Advancement of Teaching shows a total endowment of $3,065,000 l$., and an expenditure for the year ending September 30, 1913, of 131,686l. Of this 103,888l. were distributed in retiring allowances to professors, and $16,150 l$. in pensions to their widows. Thirty-three allowances were granted during the year, making the total in force 403 , the average annual payment to an individual being $340 l$. The total distribution from the beginning has been $587,385 l$. The educational work of the foundation was separately endowed in January, I9I3, by a gift of $250,000 l$. from $\mathrm{Mr}$. Carnegie through the Carnegie Corporation of New York. This body, which is endowed with 25,000,00ol. for " the advancement and diffusion of knowledge and understanding," has five ex-officio trustees, of whom one must always be the president of the Carnegie Foundation for the Advancement of Teaching.

In connection with the foundation's work as a centre of information concerning pensions, the president, Mr. H. S. Pritchett, discusses pension systems that are maintained by half a dozen colleges, the development of new systems at Brown University, the Rockefeller Institute, and the American Museum of Natural History, the new federated pension svstem of the English universities, and the proposed system for the clergy of the Episcopal Church. Among pensions for public-school teachers the report discusses the New York City system and the new State system in Massachusetts.

At the Rockefeller Institute for Medical Research the pensions are stipendiary in character, being threequarters of the last annual salary to those retiring at the age of sixty-five, after fifteen years of service. Retirement is also permitted at the earlier age of sixty, after fifteen years of service, the pension in this event being one-half of the last annual salary, plus io per cent. for each year of service in excess of fifteen. These pensions are offered only to members NO. 2329, VOL. 93] and associate members of the institute, of whom there are now twelve. The maximum for retiring allowances is high, being set at 2000 . The rules repeat the rule of the University of Chicago, that the obligation to pay retiring allowances will be neither greater nor less than the obligation to pay salaries; so that if misfortune shall compel a percentage reduction of salaries, retiring allowances may be reduced in the same proportion."

Much of the report is devoted to the development of the educational work of the foundation into a separate division of educational inquiry. Its recent work includes a study of education in Vermont at the request of the Vermont Educational Commission, of legal education at the request of a committee of the American Bar Association, and of engineering education at the request of a joint committee representing the national engineering societies. Plans for the study of engineering education are now being completed.

The earlier educational work of the foundation is continued in the report by commendation of the present tendency of college entrance requirements toward both elevation and flexibility. The need for further improvement is shown by the fact that only 55 per cent. of the students now in American colleges are high-school graduates. The decrease in the number of medical schools in the country from 162 in 1910 to $I_{5} 5$ in $I_{91} 3$, and the rapid improvement of the better schools are commented upon with appreciation. A general study of the problems of the State regulation of higher education is provided.

An interesting tabular statement is provided which sets out the total number of students in 807 universities and colleges in the United States, and also the number of these, who, having passed college entrance examinations and requirements, rank as collegiate students. In the 807 institutions there are in all 330,832 students, of whom 183,089 are students of college grade. In each of ten States there are upwards of 10,000 students registered in these places of higher education, and the following extract from the table shows the number of students of college standing in each case.

\begin{tabular}{|c|c|c|c|c|c|c|}
\hline State & \multicolumn{3}{|c|}{ Institutions } & $\begin{array}{c}\text { Total } \\
\text { number of } \\
\text { students }\end{array}$ & & $\begin{array}{l}\text { Studants } \\
\text { of college } \\
\text { grade }\end{array}$ \\
\hline Illinois & & 40 & $\cdots$ & 26886 & $\cdots$ & 14269 \\
\hline New York & $\ldots$ & 32 & $\ldots$ & 24214 & $\ldots$ & 19365 \\
\hline Pennsylvania & $\ldots$ & 40 & $\ldots$ & 23633 & $\ldots$ & 13279 \\
\hline Ohio & $\ldots$ & 45 & $\ldots$ & 22704 & $\ldots$ & 14126 \\
\hline Indiana & $\ldots$ & 25 & $\ldots$ & 14635 & $\ldots$ & 7653 \\
\hline Massachusetts & $\ldots$ & 17 & $\ldots$ & $1434 \mathrm{I}$ & $\ldots$ & 13859 \\
\hline Iowa & $\ldots$ & 40 & $\ldots$ & $1325 \mathrm{I}$ & $\ldots$ & 6607 \\
\hline Texas & $\ldots$ & 37 & $\ldots$ & 12653 & $\ldots$ & 4405 \\
\hline Kansas & $\ldots$ & 26 & $\ldots$ & $I=563$ & .. & \\
\hline California & $\ldots$ & 19 & $\ldots$ & I 1376 & $\ldots$ & 78 \\
\hline
\end{tabular}

There has been in the last five years a marked recrudescence of State activity with regard to higher institutions of learning. In a number of States the president of the State university has been dismissed, whether justly or unjustly, in a peremptory manner. In other States there has been legislation with respect to the differentiation of State institutions. In still others the regulation of degree-granting powers has occupied the attention of legislators. On the whole, the last five years have been distinctly marked by the activity of legislative authorities concerning the State institutions, and by the evidences of some awakening as to the need for the regulation of all higher institutions of learning. Whatever may be the immediate outcome of this movement, it is probably a hopeful sign of the beginning of a successful effort to differentiate State institutions and to bring within fair limits the degree-granting powers of endowed institutions.

The report further presents a study of the financial 
status of college teachers as compared with the situation presented in a similar study published five years ago. The ordinary salary of a full professor in the institutions associated with the foundation is now $600 l$. During the last five years the salaries of instructors have risen by about $\mathrm{x} 6 l$. ; those of junior professors show a gain of from $24 l$. to $45 l$.; those of full professors show an increase from $25 l$. to $70 l$.

\section{UNIVERSITY AND EDUCATIONAL INTELLIGENCE.}

IT is announced in Science that Lafayette College is a beneficiary under the will of the late Mr. William Runkle to the amount of $20,000 l$.

News has been received by cable that Prof. ' $T$. $R$. Lyle, F.R.S., is shortly to resign his professorship in the University of Melbourne, and that in consequence the chair of natural philosophy will become vacant. The salary attaching to the post is about roool. per annum, and the new occupant of the chair will be expected to take up his duties in February next, which is the beginning of the session.

THE following gifts to higher education in the Lnited States are announced in the issue of Science for June $5:-20,000 l$. anonymously for the erection of the first of Cornell University's residential dormitories; an unrestricted gift to Harvard University of ro,oool. by Mr. Nathaniel H. Stone; 50ool. under the will of Miss Elizabeth S. Shippen to the University of Pennsylvania; and $4000 l$. and a contingent interest in one-third of a $10,000 l$. fund to the Hampton Normal and Agricultural Institute by the late Mr. Robert C. Ogden.

LORD ROSEBERY has been elected president of the University of London Club, and the following have been elected vice-presidents:- Sir Thomas Barlow, Sir Robert Blair, Sir John Rose Bradford, Dr. Sophie Bryant, Sir Edward H. Busk, Mr. Clifford B. Edgar, Lord Emmott, Sir Rickman Godlee, Sir Alfred Pearce Gould, Dr. W. P. Herringham, Prof. M. J. M. Hill, Sir Alfred Hopkinson, Sir Joseph Larmor, Sir Oliver Lodge, Sir Philip Magnus, Sir Henry A. Miers, Lord Moulton, Sir William Ramsay, Sir Henry E. Roscoe, Sir William A. Tilden, Prof. H. H. Turner, and the Right. Hon. T. McKinnon Wood. The committee has elected 9 Io original members of the club, 709 men and $20 \mathrm{I}$ women. Mr. T. Ll. Humberstone has been appointed the first secretary of the club, and it is hoped that the club-house at 19 and 2I Gower Street will be open in July or soon afterwards.

THE annual report for the present year of the Nantucket Maria Mitchell Association has been received. One of the most useful of the activities of the association has been the provision from time to time of an astronomical fellowship, to which Miss M. Harwood was reappointed in March, I9I3. Her research work, executed at the Harvard College Observatory, has included a study of several variable stars of the Algol type, for the purpose of determining accurate periods and the forms of their light curves. It is desired by the association to establish a permanent fellowship yielding annually Iool,, which will enable recent graduates of women's colleges to devote themselves for a year or more to advanced work in astronomy. A portion of the year may be spent at the Maria Mitchell Observatory and a part at Harvard College Observatory. It is hoped that one or more of these fellowships may be established by some former pupil of Miss Mitchell, open to graduates of Vassar, and that similar fellowships may be endowed for graduates of other colleges.

$$
\text { No. 2329, VOL. 93] }
$$

A REPORT on the teaching of mathematics in Australia, by Prof. H. S. Carslaw, presented to the International Commission on the Teaching of Mathematics, has just been published (Sydney: Angus and Robertson; London: Oxford University Press). The problem of mathematical teaching stands in much the same position now in Australia as it stood at home a few years ago. Reformers are struggling to improve school teaching, and they find the chief obstacle to be the external examination held by a body with a limited knowledge of the schools. New South Wales has cut the knot by deciding to substitute examinations by its own Department of Public Instruction, and Queensland and Tasmania are following suit. It is a pleasing sign that some of the examining bodies are acting on the Mathematical Association reports on teaching. The decision of the Mathematical Association Committee that the congruence theorems and the condition of parallelism should be taken as the axiomatic basis of logical geometry was not available when Prof. Carslaw's report was written, and we read that the Board of Education Circular $7 \mathrm{II}$ advocating much the same treatment is condemned by the New South Wales education authority. It is permissible to hope that this authority, which is the most open-minded in Australia, and has a high regard for the Mathematical Association, may by this last decision of the association be induced to reconsider its condemnation.

\section{SOCIETIES AND ACADEMIES. LONDON.}

Linnean Society, June 4.-Prof E. B. Poulton, president, in the chair.--Rev. G. Henslow: Darwin's alternative explanation of the origin of species, without the means of Natural Selection.-G. C. Robson : On a collection of land and freshwater gastropods from Madagascar, with descriptions of a new genus and new species. The affinities of the species examined were found to be mainly Oriental and not African.-Prof. H. H. W. Pearson : Notes on the morphology of certain structures concerned in reproduction in the genus Gnetum. This is an account of an investigation of (I) androgynous and pseudoandrogynous spikes of Gnetum gnemon; (2) the young embryosac of $G$. africanum.-Prof. C. Chilton: Deto, a subantarctic genus of terrestrial crustacea. Deto is a genus of terrestrial isopoda, established in 1837 by Guerin for the species D. echinata from the Cape of Good Hope. The genus shows a typical subantarctic distribution and emphasises the close connection between the faunas of New Zealand and South America.

\section{CAMBRIDGE.}

Philosophical Society, May 18.-Dr. Shipley, president, in the chair.-Prof. Pope and J. Read: Optically active substances of simple molecular constitution. Notwithstanding numerous attempts, it has not hitherto been possible to prepare an optically active substance containing fewer than three carbon atoms in the molecule, and the assumption has therefore been made that a considerable degree of complexity is necessary to enable the molecule to exist in stable enantiomorphous forms. After unsuccessful attempts to resolve chlorosulphoacetic acid and chlorobromomethanesulphonic acid the preparation and investigation of chloroiodomethanesulphonic acid were undertaken with a similar object in view, and eventually the resolution of this substance was effected with $d$ and $l$-hydroxyhydrindamine, strychnine and brucine. The purest optically active ammonium salt of this acid yet obtained, having $[\mathrm{M}]_{5461}+43.7^{\circ}$ in dilute aqueous 